\title{
LATE PLEISTOCENE AND HOLOCENE VEGETATION, CLIMATE DYNAMICS, AND AMAZONIAN TAXA IN THE ATLANTIC FOREST, LINHARES, SE BRAZIL
}

\author{
Antonio Alvaro Buso Junior ${ }^{1,2} \bullet$ Luiz Carlos Ruiz Pessenda ${ }^{1}$ Paulo Eduardo de Oliveira ${ }^{3} \bullet$ \\ Paulo César Fonseca Giannini ${ }^{4}$ Marcelo Cancela Lisboa Cohen ${ }^{5}$ Cecília Volkmer-Ribeiro ${ }^{6}$ \\ Sonia Maria Barros de Oliveira ${ }^{4}$ Dilce de Fátima Rossetti ${ }^{7}$. Flávio Lima Lorente ${ }^{1} \bullet$ \\ Marcos Antonio Borotti Filho ${ }^{1} \cdot$ Jolimar Antonio Schiavo $^{8} \bullet$ José Albertino Bendassolli $^{1} \bullet$ \\ Marlon Carlos França ${ }^{9}$ • José Tasso Felix Guimarães ${ }^{9}$. Geovane Souza Siqueira ${ }^{10}$
}

\begin{abstract}
Analysis of biological proxies in lake sediment and geochemical analysis of soil profiles reveal natural vegetation dynamics, with climate inferences, since the late Pleistocene in a fragment of the pristine lowland Atlantic Forest of southeastern Brazil. Carbon isotopes from soil organic matter and ${ }^{14} \mathrm{C}$ ages from the humin fraction indicate the dominance of $\mathrm{C}_{3}$ plants since $~ 17,000 \mathrm{cal} \mathrm{BP}$. Palynological analysis of a sediment core indicates the presence of Atlantic Forest vegetation since $7700 \mathrm{cal}$ BP. Changes in the relative abundance of tree ferns and palms suggest the predominance of a humid period from 7000-4000 cal BP and establishment of the modern seasonal climate at $\sim 4000$ cal BP. Data indicate maintenance of the regional forest coverage since the late Pleistocene, corroborating previous suggestions that this region was a forest refuge during less humid periods of the late Pleistocene and Holocene. Some plant taxa with currently divided distributions between Amazonia and the Atlantic Forest colonized the region since at least $7500 \mathrm{cal}$ BP, indicating an earlier connection between Amazonia and Atlantic Forest.
\end{abstract}

\section{INTRODUCTION}

According to the Instituto Brasileiro de Geografia e Estatística (IBGE 2004), 6 continental biomes occur in the Brazilian territory (Figure 1). Amazon and Atlantic Forest biomes are characterized by the dominance of forest physiognomies, mainly tropical moist broadleaf forests. Three open vegetation biomes separate these forest areas, Caatinga (dominated by xeric shrublands), Cerrado (tropical grasslands, savannas, and shrublands), and Pantanal (flooded grasslands and savannas). In southern Brazil, the Pampa biome mainly is comprised of subtropical grasslands.

The Atlantic Forest is one of the most diverse and endangered ecosystems of Earth, now reduced to $<10 \%$ of its original cover (Myers et al. 2000). Some explanations for its modern biodiversity patterns involve historical processes related to events of forest expansion and retraction. Intervals of less humid climates during the Pleistocene and Holocene may have caused retraction and fragmentation of the Atlantic Forest, with some areas presenting more stable forest cover. The region from southern Bahia to northern Espírito Santo is considered by some as an area of more stable forest coverage during the Pleistocene (Mori and Prance 1981; Prance 1982; Grazziotin et al. 2006; Cabanne et al. 2008). On the other hand, intervals of more humid climates may have allowed the expansion of the forests. Some authors consider the presence of detached taxa between the Atlantic Forest and Amazonia as evidence of ancient connections between these 2 forest biomes. These connections

\footnotetext{
${ }^{1}$ Center for Nuclear Energy in Agriculture (CENA/USP), Brazil.

${ }^{2}$ Corresponding author. Email: alvaro.buso.jr@gmail.com.

${ }^{3}$ São Francisco University, Brazil.

${ }^{4}$ Instituto de Geociências da Universidade de São Paulo, Brazil.

${ }^{5}$ Federal University of Pará, Brazil.

${ }^{6}$ Fundação Zoobotânica do Rio Grande do Sul, Brazil.

${ }^{7}$ National Institute of Space Research, Brazil.

${ }^{8}$ Universidade Estadual de Mato Grosso do Sul, Brazil.

${ }^{9}$ Programa de Pós-Graduação em Geologia e Geoquímica, Instituto de Geociências, Univ. Federal do Pará (UFPA), Brazil.

${ }^{10}$ Vale Nature Reserve; Brazil.
} 


\section{A A Buso Junior et al.}

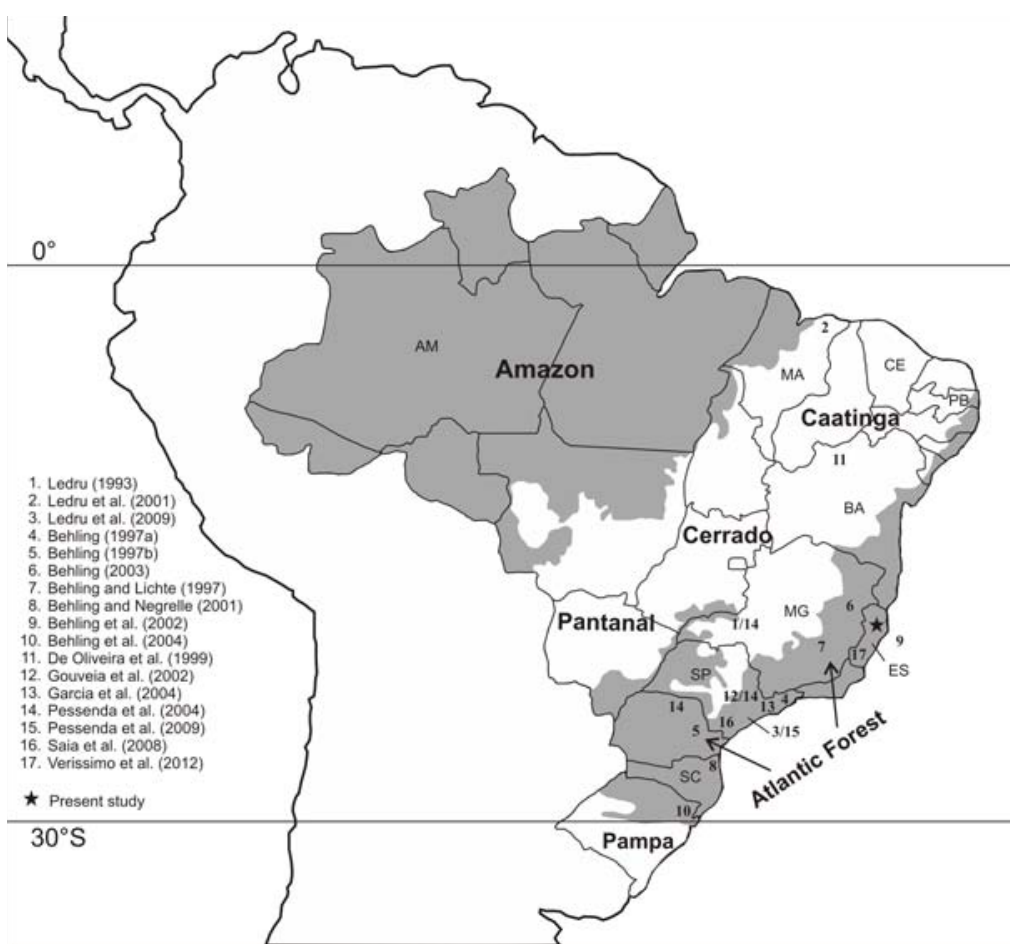

Figure 1 Map showing the original distribution of Amazon and Atlantic Forest biomes in Brazil (IBGE 2004); the relative positions of Caatinga, Cerrado, and Pantanal biomes; political map of Brazil with the identification of the states cited in the text; and the approximate sites of the paleovegetation studies discussed in the text: $\mathrm{AM}=$ Amazonas; $\mathrm{MA}=$ Maranhão; $\mathrm{CE}=$ Ceará; $\mathrm{PB}=$ Paraíba; $\mathrm{BA}=$ Bahia; $\mathrm{MG}=$ Minas Gerais; $\mathrm{ES}=$ Espírito Santo; SP = São Paulo; SC = Santa Catarina.

may have occurred during periods of wetter climates when these species could have crossed the modern Caatinga and Cerrado areas (see Fiaschi and Pirani 2009 and references herein).

Paleoenvironmental studies have contributed to a better understanding of the Atlantic Forest history during the late Quaternary, showing that it presented locally distinct responses to the climate fluctuations. For the last glacial period, studies have revealed events of forest retraction, especially during the Last Glacial Maximum (LGM), characterized by the expansion of tropical grasslands and savannas in central and western regions of the Atlantic Forest, and expansion of subtropical grasslands at its southern and southeastern areas (Behling 1997a,b, 2003; Behling and Lichte 1997; Behling et al. 2002, 2004; Gouveia et al. 2002; Pessenda et al. 2004; Saia et al. 2008; Ledru et al. 2009). Other studies have shown the maintenance of forests or forest-grassland mosaics, with no evidence of forest retraction, even during the LGM (Pessenda et al. 2009).

For the early and mid-Holocene, studies based on pollen and carbon isotopes from soil organic matter (SOM) have shown the expansion of grasslands and savannas at the Atlantic Forest biome (Behling 1997b, 2003; Behling et al. 2004; Gouveia et al. 2002; Garcia et al. 2004; Pessenda et al. 2004; Ledru et al. 2009), or the maintenance of forest-subtropical grasslands mosaics (Behling 1997a; Pessenda et al. 2009). Few studies based on palynology have demonstrated the permanence of the Atlantic Forest during the entire Holocene (e.g. Behling and Negrelle 2001). Most of these 


\section{Vegetation, Climate, Taxa at Atlantic Forest, SE Brazil}

studies propose forest expansion or modification of forest species composition during the late Holocene, in response to inferred more humid climates.

Here, we propose an interdisciplinary approach, using sediment palynology and carbon isotopes of SOM, to study vegetation dynamics, in terms of changes in biodiversity patterns and their relationship with climatic changes, undergone by the lowland Atlantic Forest during the late Pleistocene and Holocene, in the Linhares region of northern Espírito Santo State. As mentioned, some studies have suggested this region was a more stable forest area during climate oscillations of the late Quaternary.

\section{STUDY SITE}

Vale Nature Reserve (VNR) and Sooretama Nature Reserve (Sooretama) are located at the northern coast of Espírito Santo State, Brazil (Figure 2). These reserves contain remnants of primary forest, known locally as tabuleiro forest, as well as other types of natural vegetation such as seasonally flooded forests, marshes, gallery forests, restingas, and campos nativos (grasslands).

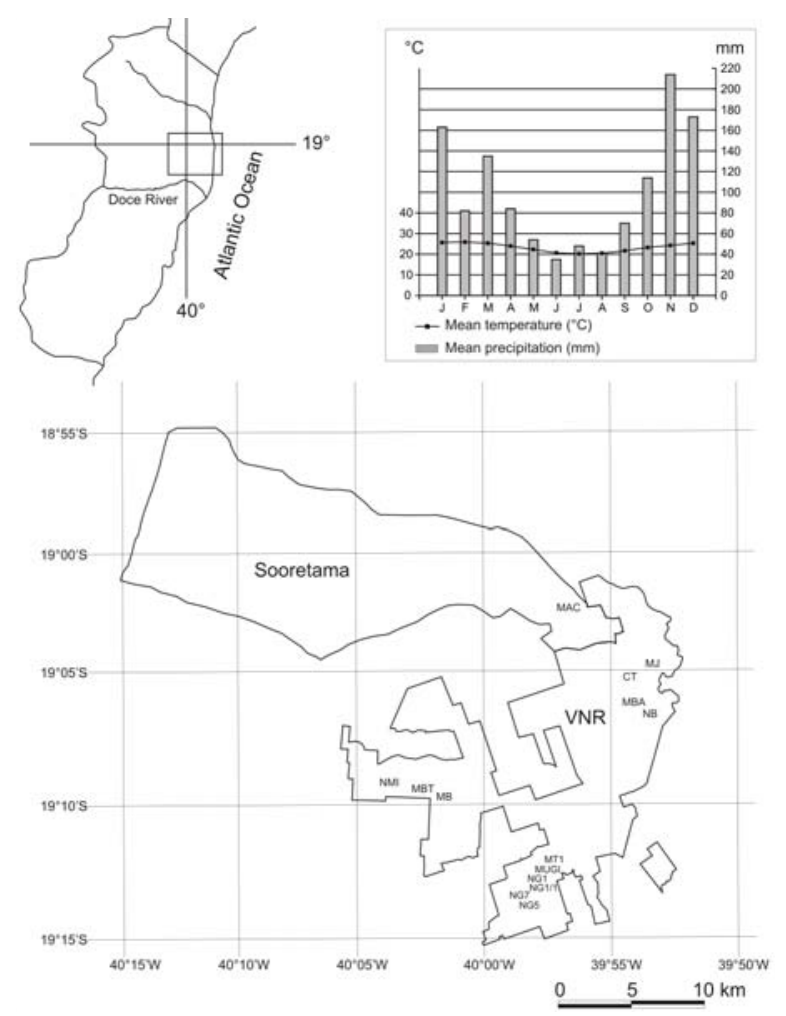

Figure 2 The study region at the NE coast of Espírito Santo State (upper left panel), climate diagram for the study site (upper right panel), and sampling sites in VNR and Sooretama nature reserves (lower panel).

Tabuleiro forest is the most representative vegetation type at VNR and Sooretama. It is a lowland dense rainforest, placed over Yellow Dystrophic Latosol, at 20-70 m above sea level (m asl), on a flat, smooth undulated terrain formed by Neogene sediments (Santos et al. 2004; Dominguez 2009). Some plant taxa in tabuleiro forests present a divided geographic distribution with Amazonian forests. Examples are the genera Glycydendron, Rinorea, Senefeldera, Symphonia, Borismene, and 


\section{A A Buso Junior et al.}

Macoubea (Lista de Espécies da Flora do Brasil 2013). The campos nativos are native grasslands interspersed among the tabuleiro forest. The soils under campos nativos at VNR were classified by Santos et al. (2004) as Espodosol. These are poorly drained sandy soils, due to the presence of a cemented B horizon, and thus are prone to flooding during the rainy season.

Precipitation patterns at the study site are controlled by the South American Monsoon System (SAMS; Garreaud et al. 2009). The regional climate is strongly seasonal with the rainy season occurring during austral summer. The mean monthly temperature is always higher than $18^{\circ} \mathrm{C}$. For the time interval from 1975 to 2002, the local climate was classified as the "Aw" type in the Köppen system, with a mean annual precipitation of $1215 \mathrm{~mm}$, mean annual temperature of $23.3^{\circ} \mathrm{C}$, and a dry season during the winter months of June to September (Figure 2).

\section{MATERIAL AND METHODS}

Carbon isotope composition $\left(\delta^{13} \mathrm{C}\right)$ of the organic matter preserved in soils can be used to study past vegetation dynamics relating to the abundance of $C_{3}$ and $C_{4}$ plants (Pessenda et al. 1996, 2004, 2009). $C_{4}$ plants (especially Poaceae and Cyperaceae) are more efficient in the use of water and usually more competent than $\mathrm{C}_{3}$ plants in relatively warmer and dryer environments. The $\delta^{13} \mathrm{C}$ of $\mathrm{C}_{3}$ plants ranges from $-32 \%$ to $-20 \%$, whereas the $\delta^{13} \mathrm{C}$ of $\mathrm{C}_{4}$ plants ranges from $-17 \%$ o to $-9 \%$, and this isotope signature may be preserved in the soil profile. Soil samples for $\delta^{13} \mathrm{C}$ analyses were collected in 10- or 20-cm intervals at forest and grassland sites (Table 1). These samples were air-dried, and the $<250-\mu \mathrm{m}$ fraction was used for carbon isotope analysis. Samples from dominant plant species and litter were collected at some sites for $\delta^{13} \mathrm{C}$ analysis. These samples were cleaned with deionized water, dried at $40{ }^{\circ} \mathrm{C}$, and grinded. Analyses were carried out at the CENA Stable Isotope Laboratory using an elemental analyzer attached to an ANCA SL 2020 mass spectrometer. $\delta^{13} \mathrm{C}$ is measured with respect to VPDB and is expressed in per mil (\%) with a standard deviation of $\pm 0.2 \%$ (Pessenda et al. 2010a).

Table 1 Sampling sites and types of analyses.

\begin{tabular}{lllll}
\hline Site $^{\mathrm{a}}$ & Description & Sampling method & Coordinates and altitude (m asl) & Analyses \\
\hline MBT & Forest & Trench & $19^{\circ} 09^{\prime} 12.30^{\prime \prime} \mathrm{S}, 40^{\circ} 02^{\prime} 44.88^{\prime \prime} \mathrm{W}(66)$ & ${ }^{14} \mathrm{C}$ \\
CT & Forest & Trench & $19^{\circ} 05^{\prime} 14.80^{\prime \prime} \mathrm{S}, 39^{\circ} 54^{\prime} 18.50^{\prime \prime} \mathrm{W}(32)$ & $\delta^{13} \mathrm{C}$ \\
MB & Forest & Hand auger & $19^{\circ} 09^{\prime} 22.56^{\prime \prime} \mathrm{S}, 40^{\circ} 02^{\prime} 32.52^{\prime \prime} \mathrm{W}(68)$ & $\delta^{13} \mathrm{C}$ \\
MT1 & Forest & Hand auger & $19^{\circ} 12^{\prime} 19.86^{\prime \prime} \mathrm{S}, 39^{\circ} 57^{\prime} 38.16^{\prime \prime} \mathrm{W}(40)$ & $\delta^{13} \mathrm{C}$ \\
NG5 & Forest & Hand auger & $19^{\circ} 13^{\prime} 25.40^{\prime \prime} \mathrm{S}, 39^{\circ} 58^{\prime} 15.30^{\prime \prime} \mathrm{W}(34)$ & $\delta^{13} \mathrm{C}$ \\
MBA & Forest & Hand auger & $19^{\circ} 06^{\prime} 34.55^{\prime \prime} \mathrm{S}, 39^{\circ} 53^{\prime} 28.90^{\prime \prime} \mathrm{W}(30)$ & $\delta^{13} \mathrm{C}$ \\
MJ & Forest & Hand auger & $19^{\circ} 04^{\prime} 56.30^{\prime \prime} \mathrm{S}, 39^{\circ} 53^{\prime} 15.30^{\prime \prime} \mathrm{W}(28)$ & $\delta^{13} \mathrm{C}$ \\
NG1 & Grassland & Hand auger & $19^{\circ} 12^{\prime} 40.80^{\prime \prime} \mathrm{S}, 39^{\circ} 57^{\prime} 50.52^{\prime \prime} \mathrm{W}(24)$ & $\delta^{13} \mathrm{C}$ \\
NG1/1 & Grassland & Hand auger & $19^{\circ} 12^{\prime} 36.50^{\prime \prime} \mathrm{S}, 39^{\circ} 57^{\prime} 48.10^{\prime \prime} \mathrm{W}(24)$ & ${ }^{14} \mathrm{C}, \delta^{13} \mathrm{C}$ \\
MUGI & Grassland & Hand auger & $19^{\circ} 12^{\prime} 29.16^{\prime \prime} \mathrm{S}, 39^{\circ} 57^{\prime} 43.32^{\prime \prime} \mathrm{W}(27)$ & $\delta^{13} \mathrm{C}$ \\
NMI & Grassland & Hand auger & $19^{\circ} 09^{\prime} 11.82^{\prime \prime} \mathrm{S}, 40^{\circ} 03^{\prime} 56.34^{\prime \prime} \mathrm{W}(56)$ & $\delta^{13} \mathrm{C}$ \\
NG7 & Grassland & Hand auger & $19^{\circ} 13^{\prime} 12.90^{\prime \prime} \mathrm{S}, 39^{\circ} 58^{\prime} 09.50^{\prime \prime} \mathrm{W}(26)$ & $\delta^{13} \mathrm{C}$ \\
NB & Grassland & Hand auger & $19^{\circ} 06^{\prime} 36.10^{\prime \prime} \mathrm{S}, 39^{\circ} 53^{\prime} 19.80^{\prime \prime} \mathrm{W}(14)$ & $\delta^{13} \mathrm{C}$ \\
MAC & Lake & Piston corer & $19^{\circ} 02^{\prime} 35.04^{\prime \prime} \mathrm{S}, 39^{\circ} 56^{\prime} 41.70^{\prime \prime} \mathrm{W}(1)$ & ${ }^{14} \mathrm{C}$, pollen \\
\hline
\end{tabular}

aSites in which were collected plants for $\delta^{13} \mathrm{C}$ analyses: MB, MT1, NG5, MBA, NG1, MUGI, NMI, NG7, NB, and MAC.

A 204-cm sediment core (MAC-C) was collected with a modified Livingston piston sediment sampler (Colinvaux et al. 1999) on a floating platform at the center of Lagoa do Macuco basin ("MAC" 


\section{Vegetation, Climate, Taxa at Atlantic Forest, SE Brazil}

site in Table 1). Lagoa do Macuco is a freshwater lake located within the Barra Seca River Valley (Figure 2). Dominant plant species around the lake were collected for $\delta^{13} \mathrm{C}$ analysis. At the ${ }^{14} \mathrm{C}$ laboratory (CENA/USP, Piracicaba), sediment subsamples were collected at 2-cm intervals of the core.

Four soil samples were selected for ${ }^{14} \mathrm{C}$ dating, 3 from a forest site (MBT) and 1 from a grassland site (NG1/1). The sample from the NG1/1 site was collected from an undetermined soil type below the cemented B horizon of the Spodosol. These soil samples were treated according to Pessenda et al. (1996) for humin extraction. Humic and fulvic acids removed during the humin extraction are mobile and can be sources of younger carbon transported downward from the shallow part of the soil. Therefore, humin is the most appropriate fraction for dating SOM.

Sixteen sediment samples from the MAC-C core were selected for ${ }^{14} \mathrm{C}$ dating. Methodology and results are presented and discussed in Buso Junior et al. (these proceedings). All the samples used in ${ }^{14} \mathrm{C}$ analysis (soil and sediment) were combusted at the ${ }^{14} \mathrm{C}$ Laboratory at CENA, and purified $\mathrm{CO}_{2}$ was sent to Isotrace Laboratory, University of Toronto, Canada, and to the University of Georgia, USA, for accelerator mass spectrometry (AMS) dating. Ages are expressed as years before present (BP) and calibrated ages (cal BP, 2s), according to the SHCal04 curve (McCormac et al. 2004) for ages from 0-11,000 cal BP, and the IntCal09 curve (Reimer et al. 2009) for ages $>11,000 \mathrm{cal} \mathrm{BP}$. The software CALIB v 6.11 (Stuiver and Reimer 1993) was used for calibrating ${ }^{14} \mathrm{C}$ ages. Calibrated ages of sediment samples were used to create an age model in the software Tilia v 1.7.16 (Grimm 1992) to interpolate ages at any undated interval in the sediment core.

Pollen analysis was carried out on 26 samples of $1 \mathrm{~cm}^{3}$, processed according to Colinvaux et al. (1999). At least 300 tree/shrub pollen grains were counted in each sample. The total pollen sum includes all pollen types and is the basis for percentage calculations. Fern spores are not included in the total pollen sum. Identification was based on the pollen reference collection of the ${ }^{14} \mathrm{C}$ Laboratory of CENA. Identified pollen and spores were grouped into mangrove trees, other trees, and shrubs, aquatics, terrestrial fern spores, and herbs. Unidentified and reworked pollen grains were classified as indeterminate. In order to identify changes in forest taxa composition, CONISS software (Grimm 1987) was used for constrained cluster analysis, which was based on trees and shrubs pollen (excluding mangrove trees) and Cyatheaceae spore counts, which are representative of forest environments.

\section{RESULTS AND DISCUSSION}

\section{Chronology}

The ${ }^{14} \mathrm{C}$ ages obtained from the humin fraction varied from $16,685-15,461 \mathrm{cal} \mathrm{BP}$ at $360-350 \mathrm{~cm}$ in the grassland site, to $7827-7669 \mathrm{cal} \mathrm{BP}$ at 200-190 cm, and 2844-2744 cal BP at 50-40 cm, in the forest site (Table 2). The ${ }^{14} \mathrm{C}$ ages obtained from the humin fraction, at forest and grassland sites, are in agreement with several naturally buried humin and charcoal samples from Anhembi, Botucatu, Jaguariúna, Piracicaba (São Paulo State), Salitre (Minas Gerais State), Barreirinhas (Maranhão State), FLONA (Ceará State), REBIO (Paraíba State), and Humaitá (Amazonas State) (Figures 1 and 3). Based on this, we suggest that the regression curve of Figure 3 can be used to infer an approximate age for deeper samples $(350-400 \mathrm{~cm})$ in this study. These samples can represent the late Pleistocene ( 17,000 cal BP).

In the MAC-C core, ${ }^{14} \mathrm{C}$ ages range from $7667-7430 \mathrm{cal} \mathrm{BP}$ at the base to modern age at the top (Figure 5). No age inversions were observed. The ages from the MAC-C core, and the age model, are presented and discussed in more detail Buso Junior et al. (these proceedings). 


\section{A A Buso Junior et al.}

Table $2{ }^{14} \mathrm{C}$ dates and calibrated ages from humin fraction of soil organic matter.

\begin{tabular}{|c|c|c|c|c|}
\hline $\mathrm{Lab}^{\mathrm{a}} \#$ & Dated material & Depth (cm) & Age (BP) & Age (cal BP; $2 \sigma$ ) \\
\hline \multicolumn{5}{|c|}{ Sampling site: MBT (forest) } \\
\hline UGAMS4270 & Humin & $40-50$ & $2720 \pm 25$ & $2844-2744$ \\
\hline UGAMS4271 & Humin & $90-100$ & $6240 \pm 30$ & 7234-6954 \\
\hline UGAMS4272 & Humin & 190-200 & $6960 \pm 30$ & 7827-7669 \\
\hline \multicolumn{5}{|c|}{ Sampling site: NG1/1 (grassland) } \\
\hline UGAMS8195 & Humin & $350-360$ & $13,280 \pm 60$ & $16,685-15,461$ \\
\hline
\end{tabular}

a UGAMS, University of Georgia, USA.

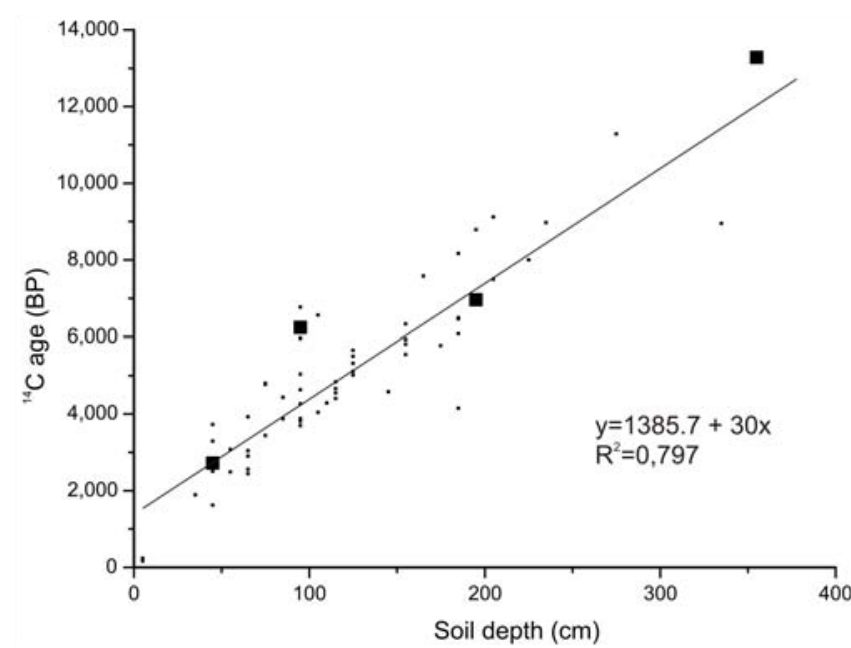

Figure 3 Soil depth ages obtained from 60 humin and charcoal ${ }^{14} \mathrm{C}$ dates and the resulting regression curve. Data from Pessenda et al. (2001, 2004, 2005, 2010b) and Vidotto et al. (2007). Ages obtained in this study (large black squares) were not included in the regression analysis.

\section{$\delta^{13} \mathrm{C}$ Values of Modern Plants and Litter}

At forest sites, $\delta^{13} \mathrm{C}$ values of dominant plant varied from $-35.8 \%$ to $-31.2 \%$ and litter varied from $-30.6 \%$ to $-28.9 \%$. At grassland sites, there was no litter accumulation and the $\delta^{13} \mathrm{C}$ values of plants ranged from $-32.4 \%$ o to $-13.4 \%$. $\delta^{13} \mathrm{C}$ of terrestrial plants from Lagoa do Macuco ranged from $-32.0 \%$ to $-13.6 \%$ (Table 3 ).

The $\delta^{13} \mathrm{C}$ values of plants and litter reflect the dominance of $\mathrm{C}_{3}$ plants. Only 2 samples showed more enriched values, characteristic of $\mathrm{C}_{4}$ plants, Lagenocarpus verticellatus (Cyperaceae, site MUGI; $\delta^{13} \mathrm{C}=-13.4 \%$ ) and Paspalum sp. (Poaceae, site MAC; $\delta^{13} \mathrm{C}=-13.6 \%$ ). Nonetheless, these species were represented only by few individuals at these sites.

\section{$\delta^{13} \mathrm{C}$ of Soil Organic Matter}

At forest sites, the $\delta^{13} \mathrm{C}$ of SOM along the soil profiles varied from $-28.0 \%$ to $-24.5 \%$ (Figure $4 \mathrm{~A}$ ). At grasslands, the $\delta^{13} \mathrm{C}$ varied from -28.9\%o to -23.7\% (Figure 4B). All soil profiles showed $\delta^{13} \mathrm{C}$ values characteristic of $\mathrm{C}_{3}$ plants (Figure 4). There is a tendency for more enriched $\delta^{13} \mathrm{C}$ values (up to $-23.7 \%$ ) at deeper soil profiles to more depleted values at the surface layers. The highest differ- 
Vegetation, Climate, Taxa at Atlantic Forest, SE Brazil

Table 3 Carbon isotope composition of litter and plant samples.

\begin{tabular}{|c|c|c|c|}
\hline Site/sample & $\delta^{13} \mathrm{C}(\%)$ & Site/sample & $\delta^{13} \mathrm{C}(\%)$ \\
\hline MB (forest) & & MJ (forest) & \\
\hline Litter & -29.2 & Litter & -30.6 \\
\hline Palicourea fulgens & -33.7 & & \\
\hline Piptadenia fruticosa & -35.1 & MUGI (grassland) & \\
\hline Sebastiania sp. & -35.5 & Byrsonima sp. & -32.4 \\
\hline Stercullia speciosa & -31.2 & Lagenocarpus verticellatus & -13.4 \\
\hline Calathea linharesana & -35.8 & Machaerium uncinatum & -30.8 \\
\hline Eriotheca macrophylla & -35.6 & Vriesea sp. & -30.9 \\
\hline MBA (forest) & & NMI (grassland) & \\
\hline Litter & -28.9 & Renvoizea trinii & -28.9 \\
\hline Marlierea excoriata & -33.9 & & \\
\hline Trichilia casaretti & -33.8 & NB (grassland) & \\
\hline Quararibea penduliflora & -33.6 & Ocotea notata & -31.0 \\
\hline Trichilia lepidota & -33.4 & Tabebuia elliptica & -25.3 \\
\hline Moldenhawera papillanthera & -32.6 & $\begin{array}{l}\text { Kielmeyera albopunctata } \\
\text { Humiria balsamifera }\end{array}$ & $\begin{array}{l}-29.1 \\
-29.0\end{array}$ \\
\hline \multicolumn{4}{|l|}{ MT1 (forest) } \\
\hline Litter & -29.9 & MAC (lake) & \\
\hline Astrocaryum aculeatissimum & -34.3 & Caperonia palustris & -29.8 \\
\hline Carpotroche brasiliensis & -32.8 & Costus sp. & -29.0 \\
\hline Amphirrhox longifolia & -33.5 & Tabebuia cassinoides & -27.1 \\
\hline Heliconia sp. & -34.7 & Thelypteris sp. & -29.2 \\
\hline \multirow[t]{2}{*}{ Poliandrococos caudescens } & -32.0 & Fuirena umbellata & -28.5 \\
\hline & & Rhynchospora gigantea & -30.2 \\
\hline NG5 (forest) & & Ludwigia nervosa & -31.4 \\
\hline Litter & -30.2 & Paspalum sp. & -13.6 \\
\hline Atalea humilis & -32.9 & Panicum sp. & -30.8 \\
\hline Pouteria sp. & -33.8 & Nephrolepsis bisserrata & -30.6 \\
\hline \multirow[t]{2}{*}{ Cecropia sp. } & -33.2 & Blechnum sp. & -28.6 \\
\hline & & Smilax brasiliensis & -30.3 \\
\hline CT (forest) & & Piper hispidum & -31.0 \\
\hline \multirow[t]{2}{*}{ Litter } & -29.6 & Blechnum serrulatum & -27.9 \\
\hline & & Anemia sp. & -31.5 \\
\hline NG1 (grassland) & & Poaceae sp. & -32.0 \\
\hline Bonnetia stricta & -27.5 & Lygodium volubile & -30.2 \\
\hline Doliocarpus lancifolius & -29.0 & Sapium glandulosum & -29.4 \\
\hline Eupatorium harvardianum & -29.1 & Myrsine rubra & -28.6 \\
\hline Lagenocarpus rigidus & -28.4 & Pityrogramma calomelanos & -30.2 \\
\hline Ocotea sp. & -30.3 & Alchornea triplinervia & -29.5 \\
\hline Paepalanthus tortilis & -29.8 & Achrosticum aureum & -26.5 \\
\hline Xyris ciliata & -29.4 & & \\
\hline
\end{tabular}

ence between samples from the same site was 3.0\%, at site NG7. This enrichment with soil depth is probably associated with the SOM decomposition (Macko and Estep 1984) and does not reflect changes in relative abundance of $\mathrm{C}_{3}$ and $\mathrm{C}_{4}$ plants in past vegetation cover. These results suggest the dominance of $C_{3}$ plants since the late Pleistocene $(\sim 17,000 \mathrm{cal} B P)$ at the forest and grassland sites. 
A A Buso Junior et al.

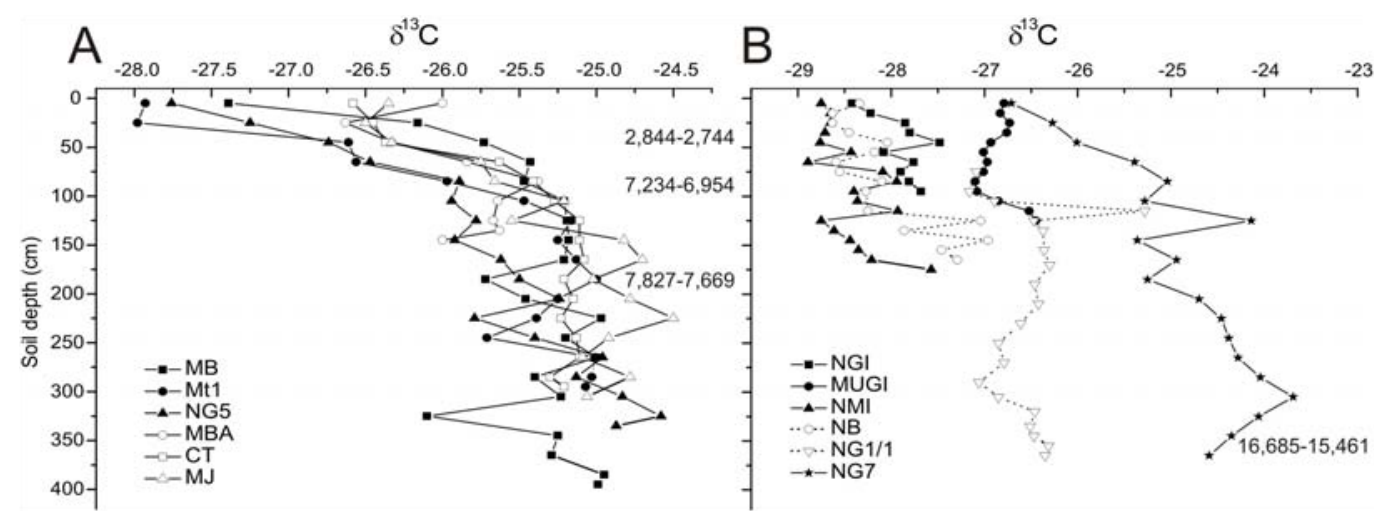

Figure 4 Variation of $\delta^{13} \mathrm{C}$ along the soil profiles and calibrated ages from humin fraction: (A) forest sites; (B) grassland sites

\section{Palynology}

Pollen analysis resulted in 141 identified pollen and spore types. These include forest and mangrove arboreal taxa, lianas, shrubs, herbs, aquatic macrophytes, terrestrial ferns, and tree ferns. Percentages of groups and of selected pollen and spore types, and the 3 clusters identified by CONISS, are presented in Figure 5.

Pollen Zone MAC-I (7623-4396 cal BP; 204-96 cm).

This zone is dominated by trees and shrubs (20-46\%), tree ferns (0-11\%), and mangrove (23-53\%). The most frequent trees and shrubs are Urticaceae/Moraceae (4-16\%), Alchornea/Aparisthmium (2-5\%), Myrtaceae (0-10\%), and Cecropia (0-6\%). When compared to pollen zones MAC-II and MAC-III (described below), MAC-I presents higher frequencies of trees and woody lianas from the Fabaceae family (0-3\%), and lower percentages of Melastomataceae/Combretaceae (0-4\%). Some tree taxa characteristic of the modern tabuleiro forest (Glycydendron and Hydrogaster), and woody lianas from the Malpighiaceae family, are exclusive of this pollen zone. Other arboreal taxa characteristic of the tabuleiro forest are present (Rinorea, Virola, Senefeldera), usually in higher frequencies than in other zones. Pollen grains from Sapotaceae (which include Chrysophyllum, Micropholis, Pouteria, and Pradosia types), an important family in tabuleiro forests, are present in almost all samples of the zone.

Pollen zone MAC-I presents rare grains of Alnus and Podocarpus. These pollen types, especially Alnus, probably reflect long-distance transport. Alnus acuminata is a tree from high Andean forests, also occurring in northern Argentina. Podocarpus is a tree from Andean montane forests and from Araucaria forests in Brazil, but may occur in lower altitudes in Amazonia and southeastern Brazil. The presence of mangrove pollen grains in this zone is consequence of the post-glacial sea-level rise, and the formation of a paleo-estuary at the site, according to Buso Junior et al. (these proceedings).

Two subzones may be distinguished in MAC-I based on the frequencies of tree ferns and Arecaceae. Subzone MAC-Ia (7623-7085 cal BP; 204-150 cm) presents lower frequencies of these taxa, Cyatheaceae ranging from $0 \%$ to $2 \%$ and Arecaceae from $0 \%$ to $2 \%$. In subzone MAC-Ib (7085$4396 \mathrm{cal}$ BP; $150-96 \mathrm{~cm}$ ), these taxa are more frequent, with tree ferns ranging from $5 \%$ to $11 \%$ and Arecaceae from $1 \%$ to $3 \%$. MAC-Ib also presents an increase in herbs and aquatic plants when compared to subzone MAC-Ia. Herb frequencies range from 6-9\% in MAC-Ia to $11-25 \%$ in MAC-Ib (especially Poaceae, 5-17\%, and Cyperaceae, 0-4\%). Aquatic plants range from 0-1\% in MAC-Ia to $0-2 \%$ in MAC-Ib (especially Typha, 0-2\%, not shown in Figure 5). 
Vegetation, Climate, Taxa at Atlantic Forest, SE Brazil

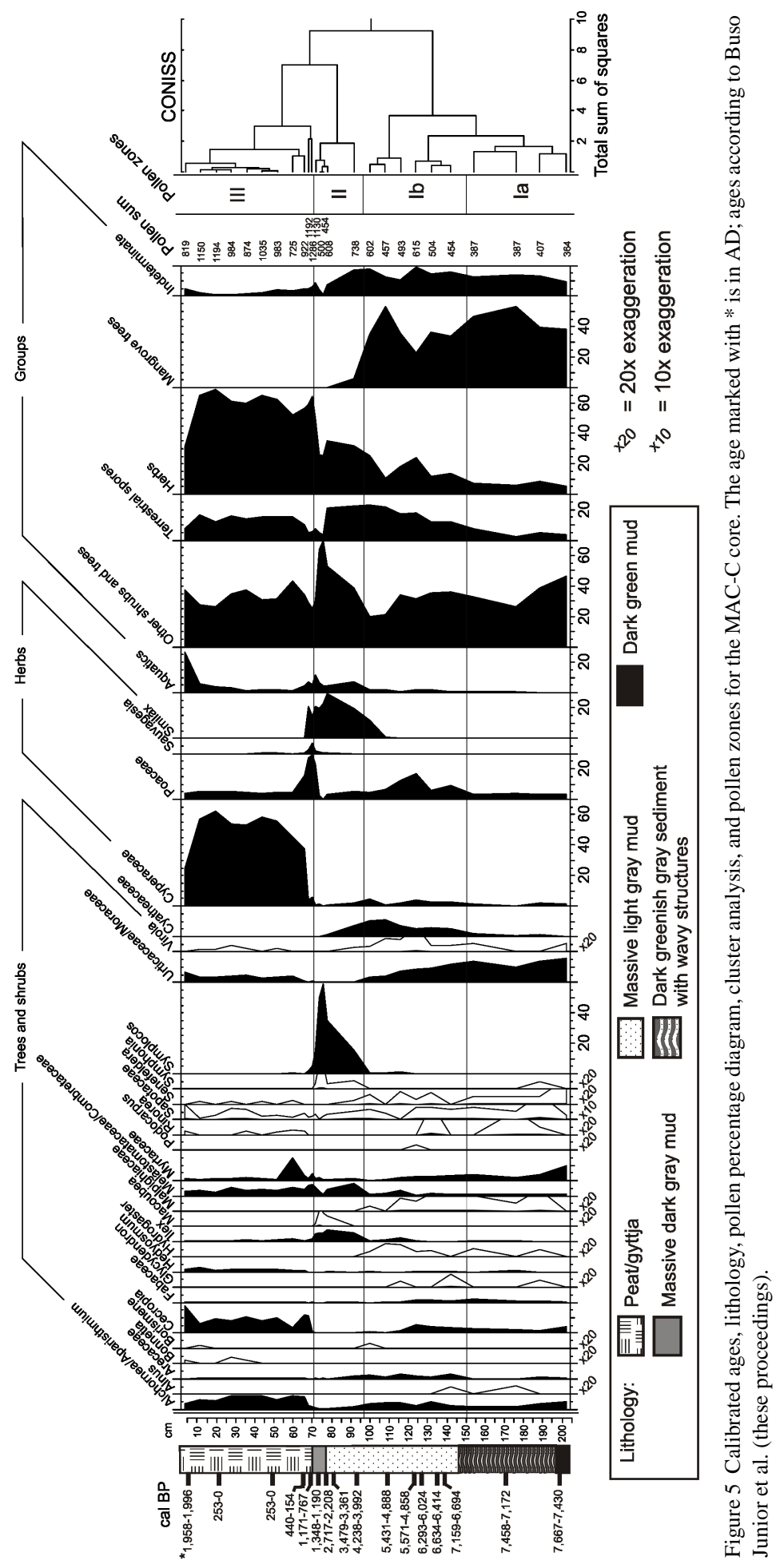




\section{A A Buso Junior et al.}

The frequencies of trees/shrubs in pollen zone MAC-I, and the relatively high frequencies of important arboreal tropical taxa like Urticaceae/Moraceae, Alchornea/Aparisthmium, and Fabaceae (which includes Mimosoideae, Copaifera, Dioclea, Machaerium, and Pterocarpus pollen types) suggest the presence of a tropical forest during the entire zone (7623-4396 cal BP). The presence of tree taxa characteristic of tabuleiro forest (Glycydendron, Hydrogaster, Rinorea, Virola, Senefeldera, and Sapotaceae), and of woody lianas, reinforce this interpretation. Higher frequencies of Cyatheaceae and Arecaceae in subzone MAC-Ib, suggest a change in the tropical forest composition, with more humid conditions during the interval 7085-4396 cal BP. In Brazil, the family Cyatheaceae is represented by tree ferns especially from the genera Cyathea and Alsophila, which are good indicators of forests with permanently humid conditions (Behling et al. 2000; Marchant et al. 2002). These more humid conditions in MAC-Ib are also supported by increased percentages of aquatic plants. Higher percentages of herb pollen in subzone MAC-Ib probably reflect the occupation of the margins of the paleo-estuary by $\mathrm{C}_{3}$ plants, according to the values of $\delta^{13} \mathrm{C}, \delta^{15} \mathrm{~N}$, and C/ $\mathrm{N}$ presented in Buso Junior et al. (these proceedings), which indicate a mixture of $\mathrm{C}_{3}$ plants and marine phytoplankton.

\section{Pollen Zone MAC-II (4396-1287 cal BP; 96-72 cm)}

Zone MAC-II is dominated by tree/shrub (30-70\%) and herb (25-50\%) pollen. The most frequent trees and shrubs are Symplocos (15-59\%), Ilex (5-7\%), Melastomataceae/Combretaceae (1-8\%), Myrtaceae (1-2\%), and Alchornea/Aparisthmium (0-2\%). Among herbs, the most frequent are Smilax (19-29\%), Poaceae (0-23\%), Cyperaceae (0-2\%) and Sauvagesia (0-2\%).

Behling and Negrelle (2001) interpreted the high percentages of Symplocos and Ilex as a successional stage before the development of the tropical forest. Some studies have shown the presence of Smilax in the colonization of disturbed areas (Boring et al. 1981; Londré and Schnitzer 2006; Shono et al. 2006). The presence of these pollen types associated with ecological succession may be explained by the colonization of sites that were previously flooded and under marine influence (Buso Junior et al, these proceedings). The presence of Symphonia, Macoubea, and Ilex, and higher percentages of the aquatic fern Salvinia (4-10\%) in pollen zone MAC-II may indicate the development of an environment associated with episodic freshwater flooding, perhaps an alluvial forest (Scarano et al. 1997; Rolim et al. 2006; Magnago et al. 2011). Reduction of the marine influence in this section of the Brazilian coast after $\sim 2500$ cal BP was proposed by Martin and Suguio (1992).

Pollen Zone MAC-III (1287 cal BP - modern; 70-00 cm).

This zone is dominated by herb and tree/shrub taxa. The most frequent trees/shrubs are Cecropia (118\%), Alchornea/Aparisthmium (2-9\%), Myrtaceae (1-15\%), Melastomataceae/Combretaceae (28\%), Urticaceae/Moraceae (0-7\%), Ilex (0-2\%), Hedyosmum (0-3\%), and Myrsine (0-1\%). Herbaceous taxa are represented mainly by Cyperaceae (4-62\%), Poaceae (4-29\%), Smilax (0-21\%), and Sauvagesia $(0-7 \%)$.

The lowermost samples in this pollen zone (70-66 cm; 1287-585 cal BP) present relatively high percentages of aquatic plants (5-7\%), especially Salvinia (1-6\%). Samples from $66 \mathrm{~cm}$ upwards (585 cal BP to present) record the colonization of the site by Cyperaceae (46-62\%) and higher percentages of aquatic plants (1-27\%), especially Potamogetom, Salvinia, and Nymphaeaceae/Pontederiaceae, reflecting the establishment of the modern environment at the study site, which is comprised of the floodplain of the Barra Seca River and by a freshwater lake. The establishment of the modern environment at $\sim 600 \mathrm{cal} \mathrm{BP}$ is corroborated by carbon and nitrogen analyses presented in Buso Junior et al. (these proceedings). These $\delta^{13} \mathrm{C}$ results also indicate that the modern terrestrial 
environment around the MAC site is dominated by $\mathrm{C}_{3}$ plants, corroborating the $\delta^{13} \mathrm{C}$ results obtained in the present study from terrestrial plants surrounding this site (Table 3).

\section{Late Pleistocene Climate}

$\delta^{13} \mathrm{C}$ analyses of SOM at the forest sites suggest the maintenance of forest vegetation since the late Pleistocene ( 17,000 cal BP). This means that enough humidity was available for the Atlantic Forest in northern Espírito Santo State during this period. According to Cruz et al. (2005, 2006b), the $\delta^{18} \mathrm{O}$ values in speleothems collected in caves of the Santa Catarina and São Paulo states suggest more intense summer monsoon over southeastern Brazil during the late glacial ( 20,000-13,000 cal BP), a period of increased summer insolation in the Southern Hemisphere.

\section{Holocene Climate}

In the present study, carbon isotopes from SOM suggest the dominance of $\mathrm{C}_{3}$ plants during the Holocene when palynological evidence points to a tropical forest since $\sim 7700 \mathrm{cal} B$ B. Ledru et al. (1998) hypothesized that during the early Holocene, polar advections reached lower latitudes in South America and were responsible for maintaining relatively wet climates. Cruz et al. (2006a) studied carbon and oxygen isotopes in the Bt2 speleothem in Santa Catarina State, southern Brazil, and found evidence of more frequent and intense cold episodes during the early Holocene. In the MAC-C core, the presence of Alnus and Podocarpus pollen grains, likely originating from southern South America and from the montane vegetation of southeastern Brazil, respectively, may indicate that southern polar air masses reached the region of Linhares during the early Holocene, causing frontal precipitation and leading to a humid climate that allowed the maintenance of the forest.

From subzone MAC-Ib to the beginning of zone MAC-II (7085-4176 cal BP), higher percentages of fern spores (especially Cyatheaceae) and pollen grains from Arecaceae suggest this interval to be the most humid period recorded in MAC-C. One possible explanation for this humidity is the gradual intensification of the summer monsoon system in South America due to the gradual migration of the Intertropical Convergence Zone (ITCZ) to southern positions, as a response to increased summer insolation in the Southern Hemisphere (Ledru et al. 1998; Wanner et al. 2008). During this period, high humidity levels at Linhares should be maintained during the entire year, as a consequence of the winter humidity caused by the advection of polar air masses, which reached the region more frequently than today, and increased summer precipitation due to the intensification of the monsoon system. Based on speleothem records, Cruz et al. (2005) found a gradual increase in the monsoon summer precipitation in southern Brazil during the Holocene, especially from $7000 \mathrm{cal}$ BP. Some paleoenvironmental studies have already proposed this more humid period during the mid-Holocene for the region of the Atlantic Forest biome. At the Volta Velha lowlands, Santa Catarina State, southern Brazil, Behling and Negrelle (2001) inferred wetter climate during the mid-Holocene in comparison with the early Holocene, and found a maximum in Cyathea spores at 7700 cal BP. Nonetheless, the authors do not propose a climatic mechanism. At Serra do Caparaó, Espírito Santo State, Veríssimo et al. (2012) found a gradual increase in the diversity and abundance of montane forest taxa in the interval 9000-2700 cal BP, suggesting an increase in humidity or rainfall.

After $\sim 4000 \mathrm{cal}$ BP, Cyatheaceae becomes absent or rare in MAC-C. This may be explained by the establishment of present seasonal climate, with a dry season, reflecting the modern position of the ITCZ. This interpretation is in agreement with Ledru et al. (1998), who suggested that during this period polar air masses became most of the time restricted to southern latitudes. It is also in agreement with $\delta^{18} \mathrm{O}$ from speleothems from southern and southeastern Brazil, which indicate that during the mid- to late Holocene summer monsoons became more intense (Cruz et al. 2005, 2006b). As a 


\section{A A Buso Junior et al.}

consequence, from $\sim 4000$ cal BP Linhares became dryer during winters. The establishment of the modern climate conditions in South America at $\sim 4000$ cal BP was already proposed by Marchant and Hooghiemstra (2004), Wanner et al. (2008), and Wanner and Brönnimann (2012).

Holocene climate inferences originating from this study for the region of Linhares are illustrated in Figure 6. During the early Holocene, polar advections provided enough humidity and allowed the maintenance of the tropical forest. This is inferred in MAC-C from the presence of Alnus pollen grains, which were probably transported by air masses from southern South America. During the mid-Holocene ( 7000 to 4000 cal BP), increasing summer insolation in the Southern Hemisphere led to increasing summer monsoons, which in conjunction with continued frequent polar advections, caused the most humid period in the Linhares region, probably without a dry season. This is recorded in the MAC-C core as higher percentages of Cyatheaceae spores and Arecaceae pollen grains. The modern seasonal climate was established from $\sim 4000 \mathrm{cal} B$, when summer insolation reached values similar to the present, and the ITCZ migrated southward. In this seasonal climate, the existence of a dry period during austral winter led to decreased Cyatheaceae and Arecaceae percentages.

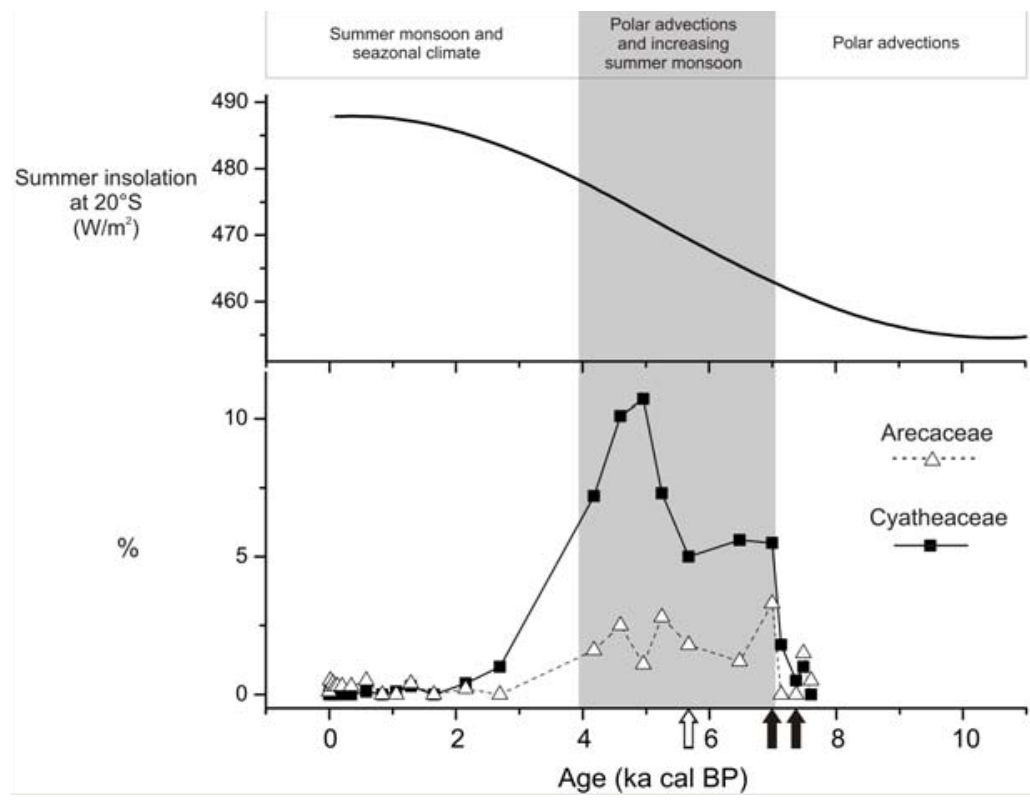

Figure 6 Climatic inferences for the Linhares region during the Holocene (upper panel); austral summer insolation at $20^{\circ} \mathrm{S}$ (middle panel); Arecaceae and Cyatheaceae percentages, and Alnus (black arrows) and Podocarpus (white arrow) occurrences in the MAC-C core (lower panel). Insolation is according to Laskar et al. (2004).

\section{Amazonian Taxa in Atlantic Forest}

Mori and Prance (1981) suggested that the development of Cerrado and Caatinga vegetation, after the onset of increased aridity during the Neogene, could have caused the fragmentation of a former widespread forest body into the Amazonia and Atlantic Forest biomes. Santos et al. (2007) reached a similar conclusion, and also suggested that more recent connections could have occurred through the region modernly occupied by the Caatinga, during more humid periods of the Quaternary, when floodplain and gallery forests expanded and allowed floristic exchanges between the Amazon and Atlantic Forest. Based on genetic patterns of non-volant small mammals, Costa (2003) also sug- 
gested Pleistocene connections between Amazonia and Atlantic Forest biomes through Caatinga and Cerrado areas during wetter climate periods. Oliveira-Filho and Ratter (1995) verified that some tree species from Amazonia and the Atlantic Forest can penetrate the modern Cerrado area via gallery forests, and suggested that these forests could have allowed the migration of Amazonia and Atlantic Forest plant species during wetter periods of the Quaternary.

Some pollen studies at places currently occupied by Cerrado and Caatinga biomes show the expansion of forest physiognomies during the late Quaternary. Ledru (1993) observed expansions of araucaria forests and semi-deciduous forests during the late Glacial and early Holocene, at Salitre. At Lagoa do Caçó, Ledru et al. (2001) found increased frequencies of arboreal pollen, including Podocarpus, during the late Pleistocene and early Holocene. De Oliveira et al. (1999) found that during the early Holocene some forest taxa from lowland Amazonia and Atlantic Forest colonized the region of the middle São Francisco River, in northern Bahia (Figure 1).

Some genera of trees and woody lianas characteristic of the Amazon biome, and that currently present a divided distribution between Amazonia and Atlantic Forest, were found in the MAC-C record since $\sim 7500$ cal BP: Glycydendron; Rinorea; Senefeldera; and Symphonia. Other genera appear more recently: Borismene ( 4600 cal BP); Macoubea ( 2700 cal BP); and Bonnetia (modern). The findings show that these Amazon taxa are present in the Atlantic Forest since at least $\sim 7500$ cal BP, and suggest that a hypothesized connection between Amazonia and Atlantic Forest occurred before this age, corroborating the conclusions of the studies presented above.

\section{Atlantic Forest Refugia}

Mori and Prance (1981) and Prance (1982) have suggested that patterns of plant taxa distribution in the Atlantic Forest may reflect the existence of ancient forest refugia during periods of forest retraction. Prance (1982) proposed the Bahia forest refuge, a coastal area from the southern Bahia to northern Espírito Santo states. Other authors, based on the molecular phylogeography of forest vertebrates in the Atlantic Forest biome, have found genetic patterns that may be the result of events of forest expansion and retraction during the late Quaternary (Grazziottin et al. 2006; Cabanne et al. 2008). These genetic patterns also suggest the section of the Atlantic Forest from São Paulo to southern Bahia as an area of forest stability during the late Quaternary. As already discussed, several paleoenvironmental studies found evidence of forest retraction of the Atlantic Forest during the late Pleistocene and Holocene. Considering these studies and the evidence of the maintenance of the tropical forest at Linhares since $\sim 17,000 \mathrm{cal} \mathrm{BP}$, we suggest that this work corroborates the hypothesis about the existence of sites with forest stability during Quaternary climatic oscillations, especially for the area from the southern Bahia and northern Espírito Santo states (Prance 1982; Grazziottin et al. 2006; Cabanne et al. 2008).

\section{CONCLUSION}

The relevance of this study relies on the following aspects: (i) that the Atlantic Forest at the study site was not subjected to forest retraction since $\sim 17,000 \mathrm{cal}$ BP, corroborating studies that suggest this region as part of a wider area of stable forest cover during late Quaternary climatic cycles; (ii) vegetation responses to the precession cycle during Holocene; (iii) inferences about the paleoclimate of the region, as relatively humid from $\sim 17,000$ cal BP to today, more humid during the interval of $\sim 7000-4000$ cal BP, and with the establishment of the modern seasonal climate at $\sim 4000 \mathrm{cal}$ BP; and (iv) the colonization of the Atlantic Forest by some Amazonian arboreal taxa since at least $\sim 7500$ cal BP. 


\section{A A Buso Junior et al.}

\section{ACKNOWLEDGMENTS}

The authors would like to thank Vale Nature Reserve (Linhares, Brazil) for the field support, and an anonymous reviewer for important contributions to this paper. This work was funded by Fundação de Amparo à Pesquisa do Estado de São Paulo (FAPESP), grants 2007/03615-5, 2007/06222-4, 2010/18091-4, and 2011/00995-7.

\section{REFERENCES}

Behling H. 1997a. Late Quaternary vegetation, climate and fire history from the tropical mountain region of Morro de Itapeva, SE Brazil. Palaeogeography, Palaeoclimatology, Palaeoecology 129:407-22.

Behling H. 1997b. Late Quaternary vegetation, climate and fire history of the Araucaria forest and campos region from Serra Campos Gerais, Paraná State (south Brazil). Review of Palaeobotany and Palynology 97: 109-21.

Behling H. 2003. Late glacial and Holocene vegetation, climate and fire history inferred from Lagoa Nova in the southeastern Brazilian lowland. Vegetation History and Archaeobotany 12:263-70.

Behling H, Lichte M. 1997. Evidence of dry and cold climatic conditions at glacial times in tropical Southeastern Brazil. Quaternary Research 48:348-58.

Behling H, Negrelle RB. 2001. Tropical rain forest and climate dynamics of the Atlantic Lowland, Southern Brazil, during the Late Quaternary. Quaternary Research 56:383-9.

Behling H, Arz HW, Pätzold J, Wefer G. 2000. Late Quaternary vegetational and climate dynamics in northeastern Brazil, inferences from marine core GeoB3104-1. Quaternary Science Reviews 19:981-94.

Behling H, Arz HW, Pätzold J, Wefer G. 2002. Late Quaternary vegetational and climate dynamics in southeastern Brazil, inferences from marine cores GeoB 3229-2 and GeoB 3202-1. Palaeogeography, Palaeoclimatology, Palaeoecology 179:227-43.

Behling H, Pillar VP, Orlóci L, Bauermann SG. 2004. Late Quaternary Araucaria forest, grassland (campos), fire and climate dynamics, studied by high-resolution pollen, charcoal and multivariate analysis of the Cambará do Sul core in southern Brazil. Palaeogeography, Palaeoclimatology, Palaeoecology 203:27797.

Boring LR, Monk CD, Swank WT. 1981. Early regeneration of a clear-cut southern Appalachian forest. Ecology 62(5):1244-53.

Buso Junior AA, Pessenda LCR, De Oliveira PE, Giannini PCF, Cohen MCL, Volkmer-Ribeiro C, Oliveira SMB, Favaro DIT, Rossetti DF, Lorente FL, Borotti Filho MA, Schiavo JA, Bendassolli JA, França MC, Guimarães JTF, Siqueira GS. From an estuary to a freshwater lake: a paleo-estuary evolution in the context of Holocene sea-level fluctuations, SE Brazil. $R a$ diocarbon, these proceedings, doi:10.2458/ azu_js_rc.55.16210.
Cabanne GS, d’Horta FM, Sari EHR, Santos FR, Miyaki CY. 2008. Nuclear and mitochondrial phylogeography of the Atlantic forest endemic Xiphorhynchus fuscus (Aves: Dendrocolaptidae): biogeography and systematics implications. Molecular Phylogenetics and Evolution 49:760-73.

Colinvaux P, De Oliveira PE, Patiño JEM. 1999. Amazon Pollen Manual and Atlas. Manual e Atlas Palinológico da Amazônia. Amsterdam: Harwood Academic Publishers.

Costa LP. 2003. The historical bridge between the Amazon and the Atlantic Forest of Brazil: a study of molecular phylogeography with small mammals. Journal of Biogeography 30:71-86.

Cruz Jr FW, Burns SJ, Karmann I, Sharp WD, Vuille M, Cardoso AO, Ferrari JA, Dias PLS, Viana Jr O. 2005. Insolation-driven changes in atmospheric circulation over the past 116,000 years in subtropical Brazil. $\mathrm{Na}$ ture 434(7029):63-6.

Cruz Jr FW, Burns SJ, Karmann I, Sharp WD, Vuille M, Ferrari JA. 2006a. A stalagmite record of changes in atmospheric circulation and soil processes in the Brazilian subtropics during the Late Pleistocene. Quaternary Science Reviews 25:2749-61.

Cruz Jr FW, Burns SJ, Karmann I, Sharp WD, Vuille M. 2006b. Reconstruction of regional atmospheric circulation features during the late Pleistocene in subtropical Brazil from oxygen isotope composition of speleothems. Earth and Planetary Science Letters 248:495507.

De Oliveira PE, Barreto AMF, Suguio K. 1999. Late Pleistocene/Holocene climatic and vegetational history of the Brazilian Caatinga: the fossil dunes of the middle São Francisco River. Palaeogeography, Palaeoclimatology, Palaeoecology 152:319-37.

Dominguez JML. 2009. The coastal zone of Brazil. In: Dillenburg SR, Hesp PA, editors. Geology and Geomorphology of Holocene Coastal Barriers of Brazil. Berlin: Springer-Verlag. p 17-46.

Fiaschi P, Pirani JR. 2009. Review of plant biogeographic studies in Brazil. Journal of Systematics and Evolution 47(5):477-96.

Garcia MJ, De Oliveira PE, Siqueira E, Fernandes RS. 2004. A Holocene vegetational and climatic record from the Atlantic rainforest belt of coastal State of São Paulo, SE Brazil. Review of Palaeobotany and Palynology 131:181-99.

Garreaud RD, Vuille M, Compagnucci R, Marengo J. 


\section{Vegetation, Climate, Taxa at Atlantic Forest, SE Brazil}

2009. Present-day South American climate. Palaeogeography, Palaeoclimatology, Palaeoecology 281: 180-95.

Gouveia SEM, Pessenda LCR, Aravena R, Boulet R, Scheel-Ybert R, Bendassolli JA, Ribeiro AS, Freitas HA. 2002. Carbon isotopes in charcoal and soils in studies of paleovegetation and climate changes during the late Pleistocene and the Holocene in the southeast and centerwest regions of Brazil. Global and Planetary Change 33:95-106.

Grazziotin FG, Monzel M, Echeverrigaray S, Bonatto SL. 2006. Phylogeography of the Bothrops jararaca complex (Serpentes: Viperidae): past fragmentation and island colonization in the Brazilian Atlantic Forest. Molecular Ecology 15:3969-82.

Grimm EC. 1987. CONISS: a Fortran 77 program for stratigraphycally constrained cluster analysis by the method of incremental sum of squares. Computers and Geosciences 13(1):13-35.

Grimm EC. 1992. Tilia and Tilia-graph: pollen spreadsheet and graphics program. Program and Abstracts, 8th International Palynological Congress. Aix-enProvence. p 56.

Instituto Brasileiro de Geografia e Estatística (IBGE). 2004. Mapa de biomas do Brasil - primeira aproximação.

Laskar J, Robutel P, Joutel F, Gastineau M, Correia ACM, Levrard B. 2004. A long-term numerical solution for the insolation quantities of the Earth. Astronomy and Astrophysics 428:261-85.

Ledru MP. 1993. Late Quaternary environmental and climatic changes in central Brazil. Quaternary Research 39:90-8.

Ledru MP, Salgado-Labouriau ML, Lorscheitter ML. 1998. Vegetation dynamics in Southern and Central Brazil during the last 10,000 yr. BP. Review of Palaeobotany and Palynology 99:131-42.

Ledru MP, Cordeiro RC, Dominguez JML, Martin L, Mourguiart P, Sifeddine A, Turcq B. 2001. Late-Glacial cooling in Amazonia inferred from pollen at Lagoa do Caçó, Northern Brazil. Quaternary Research 55:47-56.

Ledru MP, Mourguiart P, Riccomini C. 2009. Related changes in biodiversity, insolation and climate in the Atlantic rainforest since the last interglacial. Palaeogeography, Palaeoclimatology, Palaeoecology 271: 140-52.

Lista de Espécies da Flora do Brasil. 2013. http://floradobrasil.jbrj.gov.br. Acessed 27 October 2012.

Londré RA, Schnitzer SA. 2006. The distribution of lianas and their change in abundance in temperate forests over the past 45 years. Ecology 87(12):2973-8.

Macko SA, Estep MLF. 1984. Microbial alteration of stable nitrogen and carbon isotopic compositions or organic matter. Organic Geochemistry 6:787-90.

Magnago LFS, Martins SV, Pereira OJ. 2011. Floristic heterogeneity of phytocenoses restinga in Rio de Janeiro and Espírito Santo states, Brazil. Revista Árvore
35(2):245-54.

Marchant R, Almeida L, Behling H, Berrio JC, Bush M, Cleef A, Duivenvoorden J, Kappelle M, De Oliveira PE, Oliveira-Filho AT, Lozano-García S, Hooghiemstra H, Ledru MP, Ludlow-Wiechers B, Markgraf V, Mancini V, Paez M, Prieto A, Rangel O, Salgado-Labouriau ML. 2002. Distribution and ecology of parent taxa of pollen lodged within the Latin America Pollen Database. Review of Palaeobotany and Palynology 121:1-75.

Marchant R, Hooghiemstra H. 2004. Rapid environmental change in African and South American tropics around 4000 years before present: a review. Earth-Science Reviews 66:217-60.

Martin L, Suguio K. 1992. Variation of coastal dynamics during the last 7000 years recorded in beach-ridge plains associated with river mouths: example from the central Brazilian coast. Palaeogeography, Palaeoclimatology, Palaeoecology 99:119-40.

McCormac FG, Hogg AG, Blackwell PG, Buck CE, Higham TFG, Reimer PJ. 2004. SHCal04 Southern Hemisphere calibration, 0-11.0 cal kyr BP. Radiocarbon 46(3):1087-92.

Mori SA, Prance GT. 1981. The "sapucaia” group of Lecythis (Lecythidaceae). Brittonia 33(1):70-80.

Myers N, Mittermeier RA, Mittermeier CG, Fonseca GAB, Kent J. 2000. Biodiversity hotspots for conservation priorities. Nature 403(6772):853-8.

Oliveira-Filho AT, Ratter JA. 1995. A study of the origin of central Brazilian forests by the analysis of plant species distribution patterns. Edinburgh Journal of Botany 52(2):141-94.

Pessenda LCR, Aravena R, Melfi AJ, Telles ECC, Boulet R, Valencia EPE, Tomazello M. 1996. The use of carbon isotopes $\left({ }^{13} \mathrm{C},{ }^{14} \mathrm{C}\right)$ in soil to evaluate vegetation changes during the Holocene in central Brazil. Radiocarbon 38(2):191-201.

Pessenda LCR, Gouveia SEM, Aravena R. 2001. Radiocarbon dating of total soil organic matter and humin fraction and its comparison with ${ }^{14} \mathrm{C}$ ages of fossil charcoal. Radiocarbon 43(2B):595-601.

Pessenda LCR, Gouveia SEM, Aravena R, Boulet R, Valencia EPE. 2004. Holocene fire and vegetation changes in southeastern Brazil as deduced from fossil charcoal and soil carbon isotopes. Quaternary International 114:35-43.

Pessenda LCR, Ledru MP, Gouveia SEM, Aravena R, Ribeiro AS, Bendassolli JA, Boulet R. 2005. Holocene palaeoenvironmental reconstruction in northeastern Brazil inferred from pollen, charcoal and carbon isotope records. The Holocene 15(6):814-22.

Pessenda LCR, De Oliveira PE, Mofatto M, Medeiros VB, Garcia RJF, Aravena R, Bendassoli JA, Leite AZ, Saad AR, Etchebehere ML. 2009. The evolution of a tropical rainforest/grassland mosaic in southeastern Brazil since $28,000{ }^{14} \mathrm{C}$ BP based on carbon isotopes and pollen records. Quaternary Research 71:437-52.

Pessenda LCR, Saia SEMG, Gouveia SEM, Ledru MP, 


\section{A A Buso Junior et al.}

Sifeddine A, Amaral PGC, Bendassolli JA. 2010a. Last millennium environmental changes and climate inferences in the Southeastern Atlantic forest, Brazil. Annals of the Brazilian Academy of Sciences 82(3): 717-29.

Pessenda LCR, Gouveia SEM, Ribeiro AS, De Oliveira PE, Aravena R. 2010b. Late Pleistocene and Holocene vegetation changes in northeastern Brazil determined from carbon isotopes and charcoal records in soils. Palaeogeography, Palaeoclimatology, Palaeoecology 297:597-608.

Prance GT. 1982. A review of the phytogeographic evidences for Pleistocene climatic changes in the Neotropics. Annals of the Missouri Botanical Garden 69(3): 594-624.

Reimer PJ, Baillie MGL, Bard E, Bayliss A, Beck JW, Blackwell PG, Bronk Ramsey C, Buck CE, Burr GS, Edwards RL, Friedrich M, Grootes PM, Guilderson TP, Hajdas I, Heaton TJ, Hogg AG, Hughen KA, Kaiser KF, Kromer B, McCormac FG, Manning SW, Reimer RW, Richards DA, Southon JR, Talamo S, Turney CSM, van der Plicht J, Weyhenmeyer CE. 2009. IntCal09 and Marine09 radiocarbon age calibration curves, 0-50,000 years cal BP. Radiocarbon 51(4): $1111-50$.

Rolim SG, Ivanauskas NM, Rodrigues RR, Nascimento MT, Gomes JML, Folli DA, Couto HTZ. 2006. Composição florística do estrato arbóreo da floresta estacional semidecidual da planície aluvial do Rio Doce, Linhares, ES, Brasil. Acta Botanica Brasilica 20(3): 549-61.

Saia SEMG, Pessenda LCR, Gouveia SEM, Aravena R, Bendassolli JA. 2008. Last Glacial Maximum (LGM) vegetation changes in the Atlantic Forest, southeastern Brazil. Quaternary International 184:195-201.

Santos RD, Barreto WO, Silva EF, Araújo WS, Claessen
MEC, Paula JL, Souza JLR, Pérez DV, Souza JS. 2004. Levantamento expedito dos solos das reservas florestais de Linhares e Sooretama no estado do Espírito Santo. Embrapa Solos, Boletim de Pesquisa e Desenvolvimento 49:1-68.

Santos AMM, Cavalcanti DR, Silva JMC, Tabarelli M. 2007. Biogeographical relationships among tropical forests in north-eastern Brazil. Journal of Biogeography 34:437-46.

Scarano FR, Ribeiro KT, Moraes LFD, Lima HC. 1997. Plant establishment on flooded and unflooded patches of a freshwater swamp forest in Southeastern Brazil. Journal of Tropical Ecology 13(6):793-803.

Shono K, Davies SJ, Kheng CY. 2006. Regeneration of native plant species in restored forests on degraded lands in Singapore. Forest Ecology and Management 237:574-82.

Stuiver M, Reimer PJ. 1993. Extended ${ }^{14} \mathrm{C}$ data base and revised CALIB $3.0{ }^{14} \mathrm{C}$ calibration program. Radiocarbon 35(1):215-30.

Veríssimo NP, Safford HDF, Behling H. 2012. Holocene vegetation and fire history of the Serra do Caparaó, SE Brazil. The Holocene 22(11):1243-50.

Vidotto E, Pessenda LCR, Ribeiro AS, Freitas HA, Bendassolli JA. 2007. Dinâmica do ecótono florestacampo no sul do estado do Amazonas no Holoceno, através de estudos isotópicos e fitossociológicos. Acta Amazonica 37(3):385-400.

Wanner H, Brönnimann S. 2012. Is there a global Holocene climate mode? PAGES News 20(1):44-5.

Wanner H, Beer J, Bütikofer J, Crowley TJ, Cubasch U, Flückiger J, Goose H, Grosjean M, Joos F, Kaplan JO, Küttel M, Müller SA, Prentice IC, Solomina O, Stocker TF, Tarasov P, Wagner M, Widmann M. 2008. Mid- to Late Holocene climate change: an overview. Quaternary Science Reviews 27:1791-828. 